\title{
NSTEMI GUIDELINE DURING THE COVID-19 PANDEMIA, THE MISSING PIECE WHAT'S NEW IN THE 2020 ESC PRACTICE GUIDELINES?
}

\author{
Mădălina Badea ${ }^{1}$, Ana-Maria Balahura, ${ }^{2,3}$, Daniela Bartoş \\ ${ }^{1}$ Elias Emergency University Hospital, Bucharest, Romania \\ ${ }^{2}$ Emergency Clinical Hospital Bucharest, Bucharest, Romania \\ 3"Carol Davila" University of Medicine and Pharmacy, Bucharest, Romania \\ Corresponding author \\ Ana Maria Balahura
}

Department of Internal Medicine, Clinical Emergency Hospital Bucharest, 8 Floreasca Road, Sector 1, 014461 Bucharest, Romania

e-mails: balahura.anamaria@gmail.com, ana-maria.balahura@umfcd.ro

\begin{abstract}
According to tradition, every year, at the Congress of the European Society of Cardiology new clinical guidelines, usefull for our daily pratice, are launched. This year a new guideline for the management of non-ST-segment elevation myocardial infarction (NSTEMI) was presented. Substantial resources had been invested to sustain the research efforts in order to improve the diagnosis and therapeutic tools for this disease.

In this article we present the main differences between this guideline and the previous one, regarding the utility of the cardiac biomarkers, diagnosis and risk stratification algorithms, and last, but not least, medical and invasive treatment tools.
\end{abstract}

Keywords: NSTEMI, cardiac biomarkers, diagnosis, risk, treatment.

\section{Rezumat}

Așa cum ne-am obișnuit, în fiecare an, Congresul Societății Europene de Cardiologie ne surprinde cu lansarea unor noi ghiduri, utile pentru practica clinică. Anul acesta au fost prezentate noutățile privind managementul infarctului miocardic fără supradenivelare de segment ST (NSTEMI). Resurse substanțiale au fost investite pentru susținerea efortului de cercetare în vederea optimizării mijloacelor de diagnostic și tratament ale acestei afecțiuni.

În cadrul acestui articol vom prezenta succint principalele modificări aduse de acest ghid, care privesc utilitatea biomarkerilor cardiaci, algoritmi de diagnostic și stratificare a riscului, respectiv mijloace de tratament farmacologic și invaziv.

Cuvinte cheie: NSTEMI, biomarkeri cardiaci, diagnostic, risc, tratament. 


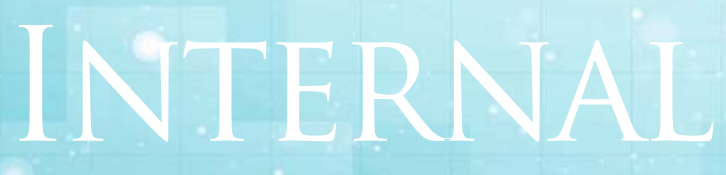

\section{General Reviews}

The European Society of Cardiology published in august 2020 a new guideline for the management of non-ST-segment elevation myocardial infarction (NSTEMI) ${ }^{(1)}$. Substantial resources have been invested to sustain the research efforts in order to improve the diagnosis and therapeutic tools for this disease.

We summarize here the main changes regarding diagnosis, risk stratification and antithrombotic and invasive treatment compared with the previous guideline which dated back in 2015.

\section{Diagnostic tools}

Cardiac biomarkers, preferably high sensitivity cardiac troponin (hs-cTn), still have a cardinal role, alongside the clinical setting and electrocardiographic (EKG) changes, for the diagnosis of NSTEMI. A dynamic elevation of cardiac troponin above the $99^{\text {th }}$ percentile of healthy individuals indicates myocardial infarction (MI).

The high sensitivity assays are recommended as they present some advantages compared to conventional assays. First, the higher sensitivity, allowing a precise differentiation between normal and "mildly" elevated values, under $100 \mathrm{ng} / \mathrm{L}$, considered to be a "grey" area with the conventional assays, difficult to detect and use as a cardiomyocyte injury marker.
These assays rapidly detect a rise in the cardiac troponin, usually in the first hour from symptom onset. Thus, it is possible to detect, faster, a larger number of cases, using "rulein" and "rule-out" algorithms.

This implies dynamic monitoring of high sensitivity cardiac troponin for the patients with the appropriate clinical setting and EKG changes for myocardial ischemia. These patients are evaluated at presentation and serially thereafter, according to the sensitivity of the assays available, after one, two or three hours. The current guideline recommends the $0 \mathrm{~h} / \mathrm{lh}$ algorithm for the detection of hs-cTn T or I, the preferred alternative being the $0 \mathrm{~h} / 2 \mathrm{~h}$ algorithm (class I, level B).

Another difference regards the cut-off thresholds for hs-cTn in order to rule-in or rule-out the MI diagnosis, which are specific for every assay and algorithm used (0h/1h or $0 \mathrm{~h} / 2 \mathrm{~h}$ ). These algorithms were developed in large derivation cohorts and then validated in large independent validation cohorts. Optimal thresholds for rule-in were selected to allow for a minimal positive predictive value of $70 \%$ and for rule-out to allow for a minimal sensitivity and negative predictive value of $99 \%$. These are applicable independent of age and renal function.

As opposed to the previous guideline, the Oh/3h algorithm should be considered when the assays are available but no longer 
represents the preferred alternative (class Ila, level B). It is not recommended to routinely measure other biomarkers such as CK, CK-MB, h-FABP or copeptin, for diagnostic purpose, in addition to hs-cTn.

Regarding the non-invasive diagnostic tools, the importance of functional evaluation (preferably with transthoracic echocardiography) remains unchanged. An improvement was made regarding the anatomical evaluation, thus coronary computed tomography angiography is recommended as an alternative to invasive angiography to exclude acute coronary syndrome (ACS), when there is a low-to-intermediate likelihood of coronary artery disease and when cardiac troponin and EKG are normal or inconclusive (class I, level A). This investigation has a high negative predictive value to exclude ACS and is usefull in order to reduce the emergency department costs and lenght of stay.

\section{Monitoring}

In the current guideline, two recommendations regarding the monitoring of patients with NSTEMI evolved from class Ila to class I indication. The first one refers to continuous rhythm monitoring for $24 \mathrm{~h}$ or until the percutaneous coronary intervention, whichever comes first, for all patients at low risk for cardiac arrhythmias. Second of all, rhythm monitoring should be extended after the first $24 \mathrm{~h}$ for the patients at increased risk for cardiac arrhythmias, which meet at least one of the following criteria:

- Haemodinamically unstable,

- Major arrhythmias,

- Left ventricle ejection fraction $<40 \%$,

- Failed reperfusion,

- Complications related to percutaneous revascularization,
- Additional critical coronary stenosis of major vessels,

- GRACE risk score ’ 140 .

\section{Risk assessment}

In order to assess the risk and predict the outcome, the European Guideline recommends clinical scores, biomarkers and electrocardiogram indicators. Regarding risk assessment, changes were made, thus the GRACE score is no longer recommended for every patient, and should be considered only in some cases (class lla, level B).

Natriuretic peptides (BNP or NT-proBNP) should be considered as they provide prognostic information besides cardiac troponin, regarding the risk of death, acute heart failure and atrial fibrillation onset (class Ila, level B).

\section{Antithrombotic treatment}

According to the results of PLATO ${ }^{(2)}$ and TRITON-TIMI $38^{(3)}$ studies, it is recommended to introduce the antithrombotic treatment with aspirin and a potent $\mathrm{P}_{2} \mathrm{Y}_{12}$ receptor inhibitor (prasugrel or ticagrelor) for the NSTEMI patients. The time point of initiation is very important.

The current guideline does not recommend pre-treatment with a $\mathrm{P}_{2} \mathrm{Y}_{12}$ receptor inhibitor before the percutaneous coronary intervention $(\mathrm{PCl})$ for those who will benefit from this investigation early, in the first 24h, when the coronary anatomy is unknown (class III, level A) as there are no large randomized studies to routinely sustain this decision.

In patient without early invasive management, the initiation of double antiplatelet inhibitors may be considered, after assessing the bleeding risk (class Ilb, level C). 


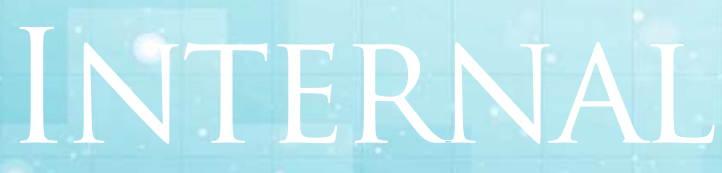

\section{General Reviews}

Prasugrel should be considered in preference to ticagrelor for NSTEMI patients who proceed to $\mathrm{PCl}$, as a result of ISAR-REACT $5^{(4)}$ study which compared the two inhibitors and proved a more significant effect of prasugrel regarding the reduction of risk of death, myocardial infarction and stroke, without a rise in the risk of bleeding (class Ila, level B). Also, ticagrelor is associated more often with bailout due to side effects.

The data derived from DAPT ${ }^{(5)}$ and PEGASUSTIMI $54^{(6)}$ studies recommended to consider extended long-term secondary prevention with double antithrombotic therapy in patients with high ischaemic risk, without increased risk of major or life-threatening bleeding (class Ila, level A). This may also be considered for those with moderate increased risk of ischaemic events (class Ilb, level A). This guideline also provides recommendations regarding risk criteria stratification, antithrombotic drugs and doses for extended treatment.

On the other hand, for those with high bleeding risk, a shorter duration for the longterm secondary prevention may be necessary. After stent implantation, with high risk of bleeding (PRECISE DAPT $\geq 25$ or ARCHBR criteria met), discontinuation of $P 2 Y_{12}$ receptor inhibitor therapy should be considered after three months (class lla, level B). For very high bleeding risk, defined as bleeding event in the previous month or the need for surgical intervention which cannot be delayed, one month double antiplatelet therapy should be considered.

\section{Anticoagulant treatment}

Peri-procedural parenteral anticoagulation is recommended, alongside the antithrombotic therapy, for all patients, after carefully evaluating the ischaemic and bleeding risk. Unfractioned heparin, enoxaparin, fondaparinux and bivalirudin are the available options.

In the previous guideline, bivalirudin was a class I recommendation as an alternative to unfractioned heparin for those who received GP IIb/IIla inhibitor. In the current guideline this indication may be considered, but the latest studies did not prove a significant benefit in the reduction of ischaemic risk, when compared to unfractioned heparin (class IIb, level A). Moreover, the MATRIX study $^{(7)}$ reported a rise in stent thrombosis with bivalirudin.

\section{Antiplatelet agents and anticoagulants for patients requiring chronic oral anticoagulation}

Stroke prevention is recommended for atrial fibrillation ( $\mathrm{AF}$ ) patients with $\mathrm{CHA}_{2} \mathrm{DS}_{2}$-VASC score $\geq 1$ in males and $\geq 2$ in females. The patients with NSTEMI, who meet these 
criteria, will follow a short period of triple antithrombotic therapy (aspirin, clopidogrel and anticoagulant), up to one week. Double antithrombotic therapy, usually with clopidogrel and anticoagulant, should follow (class I, level A). If the risk of ischaemic events is high, without high bleeding risk, triple antithrombotic therapy should be prolonged up to one month (class lla, level C).

Double antithrombotic therapy with anticoagulant and $\mathrm{P}_{2} \mathrm{Y}_{12}$ receptor inhibitor (ticagrelor or prasugrel) may be considered as an alternative to triple antithrombotic therapy with aspirin, clopidogrel and anticoagulant, in patients with a moderate or high risk of stent thrombosis, irrespective of the type of stent used (class Ilb, level C).

After 12 months, discontinuation of the antithrombotic therapy is recommended. The oral anticoagulation is continued, after assessing the bleeding risk (class I, level B).

\section{Invasive treatments}

In this guideline, early invasive strategy indication suffered some changes, and is currently recommended for those who meet at least one of the following criteria (class I, level A):

- Established NSTEMI diagnosis,

- Dynamic new or presumably new contiguous ST/T-segment changes (symptomatic or silent),

- Resuscitated cardiac arrest without ST-segment elevation or cardiogenic shock,

- GRACE risk score ' 140 .

Only one randomized study compared complete revascularization during the index intervention with serial interventions in patients with NSTEMI. It seems that complete revascularization during the index intervention is associated with less cardioand cerebrovascular events, but robust clinical data is missing. It is recommended to consider complete revascularization for all patients with multivessel disease, without cardiogenic shock (class Ila, level C) and this decision may be considered during the index intervention for the acute coronary event (class Ilb, level C).

\section{MINOCA}

A new section is dedicated to myocardial infarction with non-obstructive coronary arteries (MINOCA), comprising details about diagnosis, causes, differential diagnosis and therapy.

\section{Lipid-lowering drugs}

Statins are recommended in all NSTEMI patients. The aim is to reduce LDL-C $<55$ $\mathrm{mg} / \mathrm{dL}$ and/or by $>50 \%$ from baseline (class I, level A).

If this target is not achieved after 4-6 weeks with maximally tolerated statin dose, combination with ezetimibe is recommended, followed by proprotein convertase subtilisin/kexin type 9 (PCSK9) inhibitor (class I, level B). When a recurrence of the ischaemic event occurs within two years, while taking maximally tolerated statin dose, a LDL-c goal $<40 \mathrm{mg} / \mathrm{dL}$ may be considered (class Ilb, level B).

\section{References}

1. Collet J-P, Thiele $H$, Barbato $E$, Barthélémy $O$, Bauersachs J, Bhatt DL, et al. 2020 ESC Guidelines for the management of acute coronary syndromes in patients presenting without persistent ST-segment elevation: The Task Force for the management of acute coronary syndromes in patients presenting without persistent STsegment elevation of the European Society of Cardiology (ESC). European Heart Journal. 2020. doi: 


\section{INTERNAL}

\section{General Reviews}

10.1093/eurheartj/ehaa575.

2. Wallentin L, Becker RC, Budaj A, Cannon CP, Emanuelsson $\mathrm{H}$, Held $\mathrm{C}$, et al. Ticagrelor versus Clopidogrel in Patients with Acute Coronary Syndromes. New England Journal of Medicine. 2009;361(11):104557. doi: 10.1056/NEJMoa0904327. PubMed PMID: 19717846.

3. Wiviott SD, Braunwald E, McCabe CH, Montalescot G, Ruzyllo W, Gottlieb S, et al. Prasugrel versus Clopidogrel in Patients with Acute Coronary Syndromes. New England Journal of Medicine. 2007;357(20):2001-15. doi: 10.1056/NEJMoa0706482. PubMed PMID: 17982182.

4. Schüpke S, Neumann F-J, Menichelli M, Mayer $K$, Bernlochner I, Wöhrle J, et al. Ticagrelor or Prasugrel in Patients with Acute Coronary Syndromes. New England Journal of Medicine. 2019;381(16):1524-34. doi:
10.1056/NEJMoa1908973. PubMed PMID: 31475799.

5. Mauri L, Kereiakes DJ, Yeh RW, Driscoll-Shempp $P$, Cutlip DE, Steg PG, et al. Twelve or 30 Months of Dual Antiplatelet Therapy after Drug-Eluting Stents. New England Journal of Medicine. 2014;371(23):2155-66. doi: 10.1056/NEJMoa1409312. PubMed PMID: 25399658.

6. Bonaca MP, Bhatt DL, Cohen M, Steg PG, Storey RF, Jensen EC, et al. Long-Term Use of Ticagrelor in Patients with Prior Myocardial Infarction. New England Journal of Medicine. 2015;372(19):1791-800. doi: 10.1056/ NEJMoa1500857. PubMed PMID: 25773268.

7. Valgimigli $M$, Frigoli $E$, Leonardi $S$, Rothenbühler $M$, Gagnor A, Calabrò $P$, et al. Bivalirudin or Unfractionated Heparin in Acute Coronary Syndromes. New England Journal of Medicine. 2015;373(11):997-1009. doi: 10.1056/NEJMoa1507854. PubMed PMID: 26324049. 